\title{
POLITIK ORGANISASI DAN KOMITMEN ORGANISASIONAL SERTA DAMPAKNYA TERHADAP ORGANIZATIONAL CITIZENSHIP BEHAVIOUR (OCB) PEGAWAI APARATUR SIPIL NEGARA ( STUDI KASUS ASN DI LINGKUP SATUAN ORGANISASI PERANGKAT DAERAH KABUPATEN BOALEMO)
}

\author{
Nur Rahmi, Nur Lazimatul H. Sholehah
}

Univesitas Ichsan Gorontalo

A R T I C L E I N F O

Keywords: Political Organization, Organisasional Commitment, Organizational Citizenship Behavior

Kata Kunci: Politik Organisasi, Komitmen Organisasional, Perilaku Organisasi Kewarganegaraan

Corresponding author:

Nur Rahmi

nurrahmirahim77@gmail.com
Abstract: The research aimed to determine the influences of Political Organization and Organizational Commitment to the Organizational Citizenship Behavior (OCB) (case study on employees of state civil apparatus in the govermental organization regional units in Boalemo district). This research is causality research use of quantitative technique. The samples collection is done by using the method probability sampling by taking simple random sampling methods. The data collected through questionnaires. Some questionnaires distributed directly and some others distributed by online sistem caused by the Covid-19's effect. The variables research consists of 3 variables are Political Organization (X1) Organizational Commitment (X2) as an independent variable and Organizational Citizenship Behavior (Y) as a dependent variable. Data analyzed by multiple regression technique using SPSS 20 version software. The research results shown that Political Organization (XI) and Organizational Commitment (X2) simultaneously have had a positive impact and significantly to Organizational Citizenship Behavior (OCB). The significance value,s score 0,000 and also $F$ count $>F$ table so it can be concluded that the both Political Organization and Organizational Commitment have influences to the Organizational Citizenship Behavior (OCB). The value of the coefficient of determination $\left(R^{2}\right)$ resulting also show that there was strong correlation between the independents variables and dependent variable. Political Organization (X1) partially has not been affecting the Organizational Citizenship Behavior $(Y)$ to employees of state civil apparatus in the govermental organization regional units in Boalemo district.

Abstrak: Penelitian ini dilakukan untuk mengetahui pengaruh politik organisasi dan komitmen organisasional terhadap Organizational Citizenship Behavior $(O C B)$ dengan Studi Kasus pegawai Aparatur Sipil Negara (ASN) di Lingkup Satuan Organisasi Perangkat Daerah (SOPD) kabupatan Boalemo. Penelitian bersifat penelitian kausal yaitu penelitian yang bersifat sebab akibat, dengan pendekatan kuantitatif menggunakan metode survey. Tekhnik pengambilan sampel dilakukan dengan menggunakan metode Probability Sampling dengan mengambil metode Simple Random Sampling. Data dikumpulkan melalui kuisioner sebagian kuisioner disebarkan secara langsung dan sisanya disebarkan secara online karena terkendala Covid-19.. Variabel penelitian yang terdiri atas 3 variabel yakni 2 variabel bebas yakni Politik Organisasi (XI) dan Komitmen Organisasional (X2) dan 1 variabel terikat yaitu variabel Organisational Citizenship Behavior (Y). Data dianalisis dengan teknik analisis data berupa analisis Regresi Linear Berganda (Multiple Analysis Regression) dengan menggunakan bantuan software SPSS versi 20. Hasil penelitian menunjukkan bahwa Politik Organisasi (X1) dan Komitmen Organisasional (X2) secara simultan berpengaruh positif dan signifikan terhadap Organizational Citizenship Behavior (Y) terhadap pegawai ASN dalam lingkup SOPD Kabupaten Boalemo. 


\section{PENDAHULUAN}

\section{Latar Belakang}

Manajemen sumber daya manusia dalam sebuah organisasi ibarat sumur pengetahuan yang tidak akan pernah habis untuk digali. Kenyataan bahwa organisasi merupakan tempat berhimpunnya individuindividu dengan berbagai macam karakter merupakan keniscayaan yang tak bisa dihindarkan. Setiap individu membawa serta karakter individunya dalam berinteraksi dalam organisasi. Sebagian individu bisa bersikap proporsional dan tetap bisa mengontrol perilakunya untuk tetap bisa menjaga dan memilah batas tindakan yang membawa kepentingan organisasi dan yang mana tindakan yang membawa kepentingan pribadinya. Sebagian lagi ada yang terjebak dalam praktik-praktik tidak sehat dalam rangka mencapai kepentingan pribadinya sehingga tidak jarang perilakunya berbenturan dengan kepentingan organisasi. Dalam ranah studi perilaku organisasi tindakan individu yang berupaya untuk mencapai kepentingan pribadinya dengan cara-cara yang tidak resmi atau tidak sesuai dengan koridor yang ditetapkan oleh organisasi ini lazim diistilahkan dengan politik organisasi. Dalam tataran tertentu politik organisasi dikhawatirkan bisa membawa dampak yang buruk terhadap komitmen organisasional individuindividu didalamnya.

Organisasi birokrasi adalah salah satu model organisasi yang pegawai atau karyawannya rawan berpotensi mempraktikkan politik organisasi. Organisasi-organisasi pemerintah dalam Satuan Organisasi Perangkat Daerah (SOPD) dalam lingkup kabupaten Boalemo menurut pengamatan peneliti tidak bisa menghindarkan dari hal semacam ini. Ada banyak celah yang memungkinkan praktik ini bisa terjadi disini, mengambil contoh salah satunya bisa jadi yaitu penggunaan relasi kekuasaan, yaitu misalnya ada pegawai yang merasa punya akses dekat dengan pimpinan atau kelompok-kelompok dalam organisasi yang berperan sebagai pengambil keputusan. Mereka ini merasa dekat bisa jadi karena faktor hubungan keluarga, balas budi, merasa dekat karena menjadi anggota organisasi afiliasi yang sama atau karena sama-sama mengidolakan partai politik tertentu, sama-sama mendukung calon tertentu dalam Pemilu,dll).

Ketika praktik-praktik ini tidak sehat ini terjadi, respon para pegawai dalam organisasi ini bisa saja beragam. Ada yang merasa bahwa politik organisasi yang dijalankan oleh orang-orang tertentu ini tidak masalah, yang penting tidak merugikan dia secara pribadi dan itu tidak mengganggu komitmennya terhadap organisasi. Namun ada juga yang menanggapinya dengan " frustasi" dan menganggap bahwa apapun yang dilakukannya pada organisasi, sekeras apapun dia bekerja, sebagus apapun kinerjanya pimpinan tidak akan pernah menganggap dia atau akan mempromosikan jabatannya. sebagai contoh adanya isu promosi atau mutasi jabatan yang dipandang subjektif sebagai hasil dari praktik politik organisasi dianggap oleh beberapa pegawai dilingkup dinas-dinas pemerintah di lingkup Satuan Organisasi Perangkat Daerah di lingkup (SOPD) Kabupaten Boalemo bisa jadi menjadi salah satu salah satu kecemasan dan pada taraf tertentu ini akan lama kelamaan menurunkan komitmennya terhadap organisasi. Komitmen organisasi yang rendah menyebabkan keterikatan emosional antara pegawai dengan organisasi menjadi longgar, kerja-kerja yang dilakukan hanya sekedar memenuhi kewajiban kerja secara formal. padahal organisasi selalu berharap bahwa pegawai akan memberikan kontribusi positif bukan hanya terbatas pada kewajiban kerjanya secara formal, melainkan idealnya lebih dari kewajiban formalnya.bentuk perilaku yang secara sukarela memberikan kontribusi yang melebihi dari kewajiban formal inilah yang dalam literatur perilaku organisasi yang sering diistilahkan sebagai Organizational Citizenship Behavior (OCB). apakah faktor seperti yang penulis sebutkan diatas yakni politik organisasi maupun komitmen organisasi mempunyai pengaruh terhadap Organizational Citizenship Behavior (OCB) di kalangan pegawai ASN? Inilah faktor yang ingin ditelusuri oleh peneliti sehingga memunculkan judul 
penelitian “ Politik Organisasi dan Komitmen Organisasional Serta Dampaknya Terhadap Organizational Citizenship Behavior (Studi Kasus pegawai Aparatur Sipil Negara (ASN ) di Lingkup Satuan Organisasi Perangkat Daerah kabupatan Boalemo)".

\section{Rumusan Masalah}

Rumusan masalah dalam penelitian ini adalah apakah politik organisasi dan komitmen organisasional mempunyai pengaruh terhadap organizational citizenship behavior (OCB) pegawai Aparatur Sipil Negara dalam lingkup Satuan Kerja Perangkat Daerah (SOPD) kabupaten Boalemo?

\section{Tujuan Penelitian}

Penelitian ini dimaksudkan untuk mengetahui bahwa politik organisasi dan komitmen organisasional merupakan faktor-faktor yang berpengaruh terhadap terhadap Organizational Citizenship Behavior (OCB) pegawai Aparatur Sipil Negara dalam lingkup Satuan Kerja Perangkat Daerah (SOPD) kabupaten Boalemo.

\section{TINJAUAN TEORITIS}

\section{Politik Organisasi}

Politik organisasi sudah dideskripsikan dalam berbagai definisi. Pada prinsipnya semua berfokus pada cara- cara menggunakan kekuasaan untuk mengintervensi atau mempengaruhi pengambilan keputusan dalam sebuah organisasi atau memberikan penekanan pada perilaku anggota-anggotanya yang bersifat lebih mengutamakan kepentingan diri sendiri dan secara organisasi tidak bersanksi (Robbin, 2003). Lebih jauh Robbin mengemukakan bahwa perilaku politik dalam organisasi didefinisikan sebagai sebuah kegiatan yang tidak diminta atau bukanlah peran formal dalam sebuah organisasi tetapi sebuah kegiatan yang mencoba mempengaruhi atau mencoba mempengaruhi atau memcoba mengambil distribusi keuntu

ngan dan kerugian dalam organisasi tersebut. Politik organisasi digambarkan sebagai studi kuasa. Didalam tindakan ini menurutnya, penjelasan ini meliputi hampir berbagai macam usaha untuk memperoleh atau menggunakan pengaruh yang terjadi didalam menentukan suatu pekerjaan (Chen dan Fang, 2008). Politik organisasi dianggap sebagai sebuah tindakan yang secara sengaja dilakukan untuk mempengaruhi yang bertujuan untuk meningkatkan atau melindungi diri dari keinginan individu atau kelompok (Ahmad Firdaus Rury Pradana \& Dewi Triwijayati, 2016)

\section{Dimensi Politik Organisasi}

Adanya Praktek politik organisasi dalam sebuah organisasi dapat dilihat dari beberapa dimensi. beberapa diantaranya adalah : (1) Sportmanship, yaitu keinginan atau kemauan untuk memberikan toleransi tanpa komplain terhadap munculnya ketidaknyamanan disebabkan oleh pembagian/penentuan kerja. (2) Civic virtue, yakni adanya komitmen secara penuh karyawan terhadap organisasinya yang diwujudkan dalam bentuk-bentuk yang bisa dicontohkan misalnya selalu hadir dalam rapat, berani mengeluarkan pendapat, maupun selalu aktif berpartisipasi untuk setiap kegiatan yang diadakan perusahaan. (3) Helping behavior, adalah sikap karyawan yang secara sukarela untuk selalu membantu ataupun menolong teman/rekan kerjanya ataupun membantu menghalangi timbulnya masalah sehubungan pekerjaan dalam organisasi. (4) 
Organizational loyalty, adalah sikap loyalitas/kesetiaan karyawan kepada organisasinya, contohnya selalu berusaha menampakkan citra positif tentang organisasinya, selalu mendukung dan membela organisasi terhadap ancaman dari luar organisasi (ancaman eksternal) serta membela dan mendukung segala tujuan organisasi. (5) Organizational compliance, merupakan perilaku individu yang mematuhi segala peraturan, prosedur dan regulasi organisasi meskipun tidak ada pihak mengawasi. Individual initiative, yakni segala motif individu yang berasal dalam dirinya agar selalu mampu menjalankan kewajiban dan tugasnya dengan baik atau bahkan dapat melampui dari standar yang sudah ditetapkan. Self development, yakni sikap individu yang dengan sukarela berusaha menambah pengetahuan, meningkatkan keterampilan ataupun kapasitas individu contohnya ikut pelatihan, mengambil kursus-kursus, mengikuti seminar dan selalu berusaha untuk meng-update perkembangan terkini mengenai bidang yang ingin dikuasai (Podsakoff et.al, 2000). Politik organisasi menurut Chen dan Fang (2008) juga dapat tampil dalam bentuk organizational policies and practises ( praktek dan kebijakan organisasi), colleagues behavior (perilaku rekan kerja) serta go along to get ahead (untuk terus mencapai tujuan ).

\section{Komitmen Organisasional}

Komitmen organisasional dijelaskan sebagai loyalitas (kesetiaan) serta keterlibatan yang tinggi pada organisasi. Tinggi rendahnya komitmen karyawan berbanding lurus dengan loyalitas dan kesetiaannya. (2003 ) Komitmen organisasional merupakan sikap yang mencerminkan sejauh mana seorang individu mengenal dan merasa terikat pada organisasinya. Ketika karyawan-karyawan merasa lebih berkomitmen pada organisasinya, mereka akan memiliki dan menumbuhkan kebiasaan-kebiasaan yang bisa diandalkan, mereka berencana untuk tinggal lebih lama di dalam organisasi, dan mereka akan mencurahkan lebih banyak upaya lagi dalam bekerja (Munandar, A. S . 2004.). Ketika seorang karyawan memiliki komitmen organisasional, hal itu biasanya diwujudkan dalam bentuk sikap yang kerap dijelaskan sebagai suatu: (1) keinginan yang kuat untuk tetap menjadi anggota dari suatu organisasi tertentu; (2) Adanya kesediaan untuk mengarahkan sebanyak mungkin upaya demi kepentingan organisasinya; (3) Adanya keyakinan yang tetap untuk selalu menerima nilai-nilai dan tujuan organisasi (Robbins, 2005)

\section{Dimensi Komitmen Organizational}

Pengukuran aspek-aspek komitmen organisasional dalam sebuah organisasi bisa diadaptasi dari berbagai sudut pandang. Skala pengukuran komitmen organisasional bisa menggunakan tiga aspek yakni komitmen afektif (affective commitment), komitmen berkelanjutan (continuance commitment), dan komitmen normatif (normative commitment). Menurut mereka, perolehan skor berhubungan dengan tinggi rendahnya komitmen organisasional. artinya, semakin tinggi skor yang didapatkan, maka semakin kuat juga komitmen organisasional seorang pegawai, begitupun sebaliknya (Allen dan Meyer, 1990). Bentuk dari komitmen organisasional juga dapat dibedakan menjadi tiga dimensi menurut Katner (dalam Sopiah, 2008) yakni ; (1) ontinuance commitment atau komitmen berkelanjutan, adalah komitmen yang berhubungan dengan loyalitas dan dedikasi dari anggota organisasi dalam upayanya untuk menyinambungkan hidup organisasi serta bagaimana membuat orang-orang dalam organisasi tersebut rela berkorban serta menginvestasikan dirinya terhadap organisasi. (2) cohesion commitment atau komitmen terpadu, yakni komitmen dari anggota organisasi terhadap organisasinya yang timbul karena terjalinnya hubungan sosial dengan sesama anggotaanggota organisasi lain dilingkup organisasi tersebut. Adanya kepercayaan terhadap norma-norma yang bermanfaat dan menjadi pedoman organisasi yang menyebabkan hal ini bisa terjadi. (3) control commitment atau komitmen kontrol, yakni komitmen anggota organisasi terhadap norma-norma organisasi yang menuntun sikap anggota organisasi kearah yang diinginkannya. karena norma-norma tersebut dianggap sesuai dan mampu dalam memberikan sumbangsihnya serta berkontribusi terhadap pembentukan sikap yang diinginkannya. 


\section{Organizational Citizenship Behavior}

Organization Citizenship Behavior (OCB) diistilahkan untuk perilaku yang muncul atas dasar kebijaksanaan seorang karyawan yang dilakukan secara sukarela dan tidak ada paksaan. Perilaku ini bahkan melampaui tuntutan formal dari pekerjaan atau deskripsi pekerjaan yang formal. Istilah organizational citizenship behavior (OCB) diberikan untuk pekerja yang memberikan kontribusinya sampai melebihi deskripsi kerja formal. organizational citizenship behavior (OCB) juga didefenisikan untuk perilaku individu yang mempunyai kebebasan untuk memilih, yang secara tidak langsung diakui oleh sistem reward, dan memberi kontribusi terhadap efektifitas dan efisiensi fungsi organisasi (Andriani, Gita. 2012). Oganizational citizenship behavior adalah sebuah sikap/perilaku yang bebas dari individu yang bukan merupakan sebuah keharusan yang mutlak dilakukan sehubungan dengan peran tertentu atau deskripsi pekerjaan tertentu, ataupun sikap pribadi yang merupakan pilihan (Organ, dkk, 2006)

\section{Penelitian Sebelumnya}

Penelitian kepustakaan menunjukkan bahwa penelitan sebelumnya dengan topik yang hampir sama pernah dilakukan oleh peneliti sebelumnya dan membuahkan hasil mengenai adanya pengaruh politik organisasi terhadap Organizational Citizenship Behavior (OCB). Seperti yang pernah dilakukan oleh Cropanzano et.al,. (1997) pada 2 perusahaan manufaktur yang berjumlah 128 karyawan membuktikan bahwa politik organisasi berpengaruh terhadap OCB. penelitian lain yang dilakukan Vigoda, (2002). penelitiannya ini mengambil topik tentang praktik politik organisasi pada 3 sektor; swasta, publik dan yayasan di Israel dengan mengambil jumlah responden sejumlah 541 karyawan. ini juga menghasilkan bukti penelitian bahwa politik organisasi berpengaruh terhadap OCB. hasil yang sebaliknya justru diperoleh Gunawan (2012) ketika meneliti dengan topik penelitian yang sama. penelitian dengan mengambil responden dari 3 perusahaan tekstil yang berada di kota Bandung justru menyatakan bahwa politik organisasi tidak mempunyai pengaruh terhadap OCB. Hasil penelitian dari Gunawan et.al., (2012) ini menyatakan bahwa politik organisasi tidak berpengaruh terhadap OCB . Hasil yang sama dengan kedua peneliti sebelumnya yang disebutkan diawal yaitu yaitu Cropanzano et.al,. (1997) dan Vigoda, (2002) justru dihasilkan kembali oleh peneliti berikutnya yaitu Ahmad Firdaus Rury Pradana \& Dewie Triwijayati (2016). penelitian membuktikan bahwa politik organisasi dan komitmen organisasi berpengaruh terhadap OCB. hasil penelitian yang hasilnya sangat dinamis dan cenderung berubah-ubah ini justru menambah daya tarik topik ini bagi peneliti untuk melakukan penelitian selanjutnya. dan satu lagi keunikan yang membedakan penelitian yang akan dilakukan peneliti dibanding peneliti-peneliti sebelumnya yaitu karakteristik dari responden dan objek penelitiannya. bila dalam penelitian sebelumnya kebanyakan peneliti mengambil responden dan objek penelitian dari organisasi bisnis murni dan organisasi swasta, kali ini peneliti mengambil responden atau objek penelitian dari pegawai dari organisasi birokrasi atau organisasi pemerintahan, sebuah bentuk organisasi yang kerap diasosiasikan dengan pelayanan publik yang lamban, sistem reward dan punishment yang kurang berjalan dengan baik, dan pengangkatan pemimpin yang tidak sesuai dengan merit system sehingga hal-hal yang disebutkan ini yang disinyalir menyebabkan rendahnya kualitas pelayanan birokrasi dan lemahnya kepemimpinan dalam sebuah organisasi birokrasi ( Andriani Gita, 2012). Pengambilan sampel ini tentu saja sangat menantang bagi peneliti mengingat bisa jadi ada kemungkinan resistensi atau penolakan dari calon responden untuk memberikan data-data yang diperlukan peneliti.

\section{Kerangka Penelitian}

Pembahasan sumber daya manusia terutama yang menyangkut perilaku organisasi memang selalu menjadi tema yang menarik. Politik organisasi dan komitmen organisasional adalah dua contoh dalam perilaku 
organisasi yang kerap menarik perhatian para peneliti. Praktik politik organisasi memang bisa terjadi dalam konteks organisasi apa saja, termasuk organisasi birokrasi, seperti organisasi di lingkup dinas dalam lingkup satuan organisasi perangkat daerah di kabupaten Boalemo. Kekhasan dari karakter organisasi birokrasi yang cenderung tertutup dan diasosiasikan dengan berbagai macam stigma yang kurang bagus menjadi daya tariknya. Praktik organisasi ini tidak jarang menimbulkan dampak negatif dalam organisasi. Begitu pula dengan komitmen organisasional. Komitmen organisasional dalam organisasi harus dijaga pada level yang baik sehingga tidak menimbulkan friksi-friksi yang mengganggu. Kedua hal ini diprediksi akan membawa pengaruh terhadap terbentuknya perilaku ideal pegawai yang diinginkan organisasi yaitu organizational citizenship behavior (OCB). Bagan alir kerangka pemikiran ini dituangkan dalam bentuk bagan alir seperti di bawah ini:

\section{Gambar 1. Kerangka Penelitian}

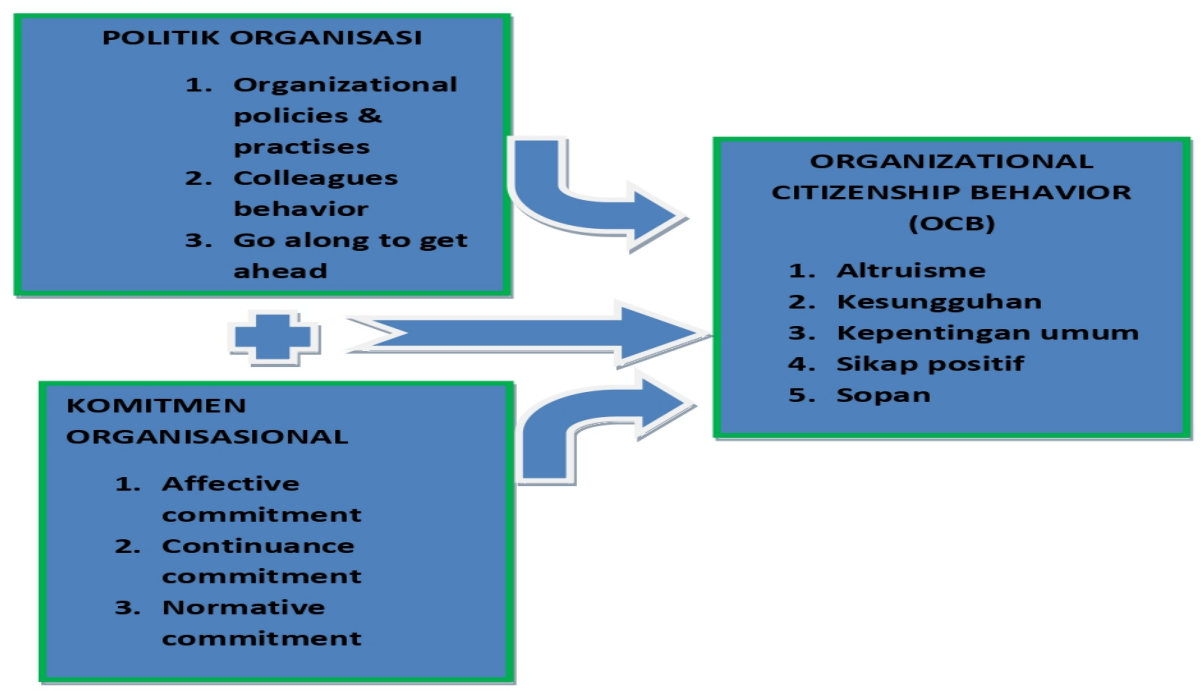

Sumber: Adaptasi Cheng \& Fang (2008), Allen \& Meyer (1990) dan Luthans (2006)

\section{METODE PENELITIAN}

\section{Jenis Penelitian}

Penelitian ini menggunakan jenis penelitian kausal yaitu penelitian yang bersifat sebab akibat. Dimaksudkan untuk mengetahui variabel mana yang merupakan variabel yang mempengaruhi/variabel penyebab dan variabel mana yang merupakan akibat. Selanjutnya akan diketahui seberapa besar pengaruh variabel independen terhadap variabel dependen. Pendekatan penelitian yang digunakan dalam penelitian ini adalah pendekatan kuantitatif dengan metode penelitian survey (Sugiyono. 2012)

\section{Metode Pengumpulan Data}

Metode pengumpulan data dalam penelitian ini dilakukan dengan menggunakan kuisioner, melakukan wawancara dengan responden, observasi, serta dengan mengumpulkan dokumentasi dan studi kepustakaan (library research) sehubungan dengan topik yang diteliti.

\section{Sumber Dan Jenis Data}


Sumber data data primer diambil dari hasil kuisioner, wawancara langsung dengan responden atau sampel penelitian. Lokasi penelitian dilakukan pada kantor dinas-dinas dilingkup satuan organisasi perangkat daerah di kabupaten Boalemo Kecamatan Tilamuta.

\section{Populasi dan Sampel}

Populasi penelitian adalah keseluruhan pegawai Aparatur Sipil Negara dalam lingkup Organisasi Perangkat Daerah di lingkup kabupaten Boalemo sebanyak 3.203 orang.

Sampel atau responden penelitian dalam hal ini adalah pegawai Aparatur Sipil Negara dalam lingkup Organisasi Perangkat Daerah di kabupaten Boalemo. Sampel ditentukan dengan menggunakan tabel Isaac dan Michael dengan tingkat kesalahan sebesar $5 \%$, sehingga sampel yang digunakan untuk penelitian ini adalah sebanyak 314 orang (Sekaran, 2003)

\section{Metode Pengambilan Sampel}

Sampel diambil dengan menggunakan teknik Probability Sampling. Probability sampling adalah teknik pengambilan sampel yang memberikan peluang yang sama kepada setiap anggota populasi untuk menjadi sampel. teknik pengambilan sampel menggunakan Simple random sampling yaitu pengambilan sampel secara acak, tanpa memperhatikan tingkatan yang ada dalam populasi Data dianalisis dengan menggunakan metode analisis Regresi Linear Berganda (multiple analysis regression) (Sugiyono, 2006). Dalam analisis regresi, variabel dikelompokkan menjadi variabel bebas dan tak bebas atau variabel terikat. variabel bebas dalam hal ini yaitu Politik Organisasi (X1) dan Komitmen Organisasional (X2). sedangkan variabel tidak bebas yaitu Organizational Citizenship Behavior (Y) analisis regresi dilakukan dengan menggunakan software SPSS versi 20.

\section{Hipotesis Penelitian}

Penelitian ini bermaksud menguji hipotesis tentang hubungan ataupun pengaruh antara politik organisasi dan komitmen organisasional terhadap Organizational Citishenship Behaviour (OCB) baik secara langsung maupun tidak langsung. Hipotesisnya dapat dirumuskan sebagai berikut:

\begin{tabular}{|l|l|}
\hline 1. & Politik Organisasi berpengaruh terhadap Organizational Citizenship Behavior (OCB) \\
\hline 2. & $\begin{array}{l}\text { Komitmen Organisasional berpengaruh terhadap Organizational Citizenship Behavior } \\
\text { (OCB) }\end{array}$ \\
\hline 3. & $\begin{array}{l}\text { Politik Organisasi melalui Komitmen Organisasional berpengaruh terhadap } \\
\text { Organizational Citizenship Behavior (OCB) }\end{array}$ \\
\hline 4 & $\begin{array}{l}\text { Politik Organisasi dan Komitmen Organisasional secara berpengaruh terhadap } \\
\text { Organizational Citizenship Behavior (OCB) }\end{array}$ \\
\hline
\end{tabular}

\section{Pengujian Instrumen Penelitian}

Dengan menggunakan kuisioner, data primer dikumpulkan dari responden. Mengingat pentingnya data tersebut, dibutuhkan kesungguhan dan kejujuran para responden dalam menjawab item-item pertanyaan dalam kuisioner. Selanjutnya hasil perolehan data yang dirancang dengan penggunaan poin skala likert five- 
point tersebut dikumpulkan kemudian dilakukan pengujian atas kesahihan data tersebut dengan menggunakan dua alat ukur yakni test of validity (uji kevalidan) dan test of realibility (tes kehandalan).

\section{Uji Validitas}

Digunakan untuk mengukur valid atau sahih tidaknya sebuah instrumen kuisioner. Sebuah kuisioner dianggap valid apabila pertanyaan-pertanyaan dalam kuisioner tersebut dianggap mampu mengungkapkan sesuatu yang akan diukur oleh kuisioner tersebut. Pengujian dilakukan menggunakan teknik korelasi Product Moment. sebuah instrumen kuisioner dianggap valid jika $p$-value yang dihasilkan sebesar 0,000 kurang dari 0,05 (Sekaran, 2003)

\section{Uji Realilitas}

Uji realibilitas atau kehandalan yakni pengujian yang menunjukkan sejauh mana hasilnya dianggap realibel atau handal atau relatif konsisten jika item-item pertanyaan dalam kuisioner itu diulang dua kali atau lebih. Koefisien realibilitas ditunjukkan oleh bagian yang berkorelasi positif antara satu dengan yang lainnya. Hasil pengukuran ditunjukkan dengan nilai Cronbach's Alpha. sebuah instrumen dianggap handal atau realibel jika nilai Cronbach's Alpha yang diperoleh lebih besar dari 0,6 (Sekaran, 2003)

\section{HASIL DAN PEMBAHASAN}

\section{Deskripsi Objek Penelitian}

Populasi dalam penelitian ini adalah seluruh ASN di wilayah kabupaten Boalemo yang tersebar di 65 SOPD dengan jumlah ASN sebanyak 3203 dengan jumlah sampel ditentukan sebanyak 314 orang. Adapun rincian sampel dan deskripsi responden baik mengenai nama-nama instansi, jenjang kepangkatan maupun golongan dapat dilihat dalam tabel berikut :

Tabel 1: Deskripsi Karakteristik Responden

\begin{tabular}{|l|l|c|c|c|c|c|}
\hline \multirow{2}{*}{ NO Nama SOPD } & \multicolumn{3}{c|}{ Golongan/Level } & \multirow{2}{*}{$\begin{array}{c}\text { Jumlah } \\
\text { Total }\end{array}$} \\
\cline { 3 - 6 } & & I & II & III & IV & 48 \\
\hline 1 & Dinas Pekerjaan Umum dan Tata Ruang & 2 & 21 & 23 & 2 & 43 \\
\hline 2 & Dinas Kelautan dan Perikanan & 0 & 15 & 26 & 2 & 43 \\
\hline 3 & Dinas Sosial Pemberdayaan Masyarakat dan Desa & 0 & 10 & 25 & 2 & 37 \\
\hline 4 & Dinas Pendidikan, Kepemudaan dan Olahraga & 1 & 23 & 28 & 9 & 61 \\
\hline 5 & $\begin{array}{l}\text { Dinas Perumahan Rakyat. Kawasan Permukiman, } \\
\text { Perhubungan dan Pertanahan }\end{array}$ & 1 & 28 & 30 & 3 & 62 \\
\hline 6 & RSUDTN & 0 & 35 & 26 & 2 & 63 \\
\hline
\end{tabular}

Sumber: data primer yang diolah, 2020

Tabel 1 menunjukkan nama-nama instansi yang merupakan bagian dari SOPD di Kabupaten Boalemo yang terpilih sebagai lokasi penelitian. ada 6 (enam) instansi antara lain Dinas Pekerjaan Umum dan Tata Ruang dengan jumlah responden sebanyak 48 orang, Dinas Kelautan dan Perikanan sebanyak 43 orang, Dinas Sosial Pemberdayaan Masyarakat dan Desa dengan jumlah responden 37 orang. Dinas Pendidikan, Kepemudaan dan Olahraga 61 orang, Dinas Perumahan Rakyat. Kawasan Permukiman, Perhubungan dan Pertanahan sebanyak 62 orang dan Rumah Sakit Umum Daerah Tani dan Nelayan (RSTDN) sebanyak 63 orang. 
Pengumpulan data pada awalnya direncanakan menggunakan instrumen kuisioner secara keseluruhan. Karena terkendala situasi pandemic Covid-19 yang menimbulkan kekhawatiran untuk melakukan kontak langsung dengan responden, maka hanya sebagan dari kuisioner yang bisa disebarkan langsung ke responden dan sebagiannya lagi disebarkan secara online dengan menggunakan aplikasi Google Form. Kuesioner yang disebarkan secara manual tersebut ditinggalkan dan diambil Kembali 7 hari setelah kuesioner diserahkan. sedangkan untuk kuisioner dalam bentuk online, waktu pengumpulannya bisa lebih flexibel dan lebih cepat lagi, kadang bisa dikumpulkan secara realtime. Adapun distribusi mengenai penyebaran kuesioner dalam tabel berikut ini:

Tabel 2: Rincian Pengiriman dan Pengembalian Kuesioner

\begin{tabular}{|c|c|c|}
\hline Keterangan & Jumlah & Presentase \\
\hline Total kuesioner yang disebar & 314 & $100 \%$ \\
\hline $\begin{array}{l}\text { Jumlah kuesioner yang } \\
\text { disebar langsung }\end{array}$ & 157 & $100 \%$ \\
\hline $\begin{array}{llr}\text { Jumlah } & \text { kuesioner } & \text { yang } \\
\text { melalui } & \text { aplikasi } & \text { Google } \\
\text { Form } & & \end{array}$ & 157 & $100 \%$ \\
\hline Kuesioner yang dapat diolah & 314 & $100 \%$ \\
\hline
\end{tabular}

Sumber: data primer yang diolah, 2020

\section{Hasil Uji Instrumen Penelitian Uji Statistik Deskriptif}

Untuk memberikan gambaran umum atas data yang telah dikumpulkan melalui penyajian informasi jumlah observasi, nilai minimum, nilai maksimum, nilai rata-rata (mean) dan standar deviasi, maka diperlukan adanya uji statistik deskriptif. Berdasarkan jumlah variabel yang diteliti dan merujuk kepada masalah yang diteliti, maka deskripsi data dibagi menjadi tiga kelompok yaitu Politik Organisasi (X1), Komitmen Organisasional (X2) dan Organisational Citizenship Behavior (Y). Hasil perhitungan statistik deskriptif untuk setiap variabel dapat dilihat secara lengkap pada lampiran. Uraian singkat hasil perhitungan statistik deskriptif tersebut dikemukakan sebagai berikut:

Tabel 3: Hasil Uji Deskriptif

\begin{tabular}{|l|r|r|r|r|}
\hline Statistics & \multicolumn{1}{|c|}{ PO } & \multicolumn{1}{|c|}{ KO } & \multicolumn{1}{|c|}{ OCB } & \\
\hline $\mathrm{N}$ & \multicolumn{1}{|l|}{ Valid } & 314 & 314 & 314 \\
\cline { 2 - 5 } & Missing & 0 & 0 & 0 \\
\hline Mean & 4.6146 & 4.6401 & 4.5701 & \\
\hline Median & 5.0000 & 5.0000 & 5.0000 & \\
\hline $\begin{array}{l}\text { Std. } \\
\text { Deviation }\end{array}$ & .51300 & .50027 & .52709 & \\
\hline Minimum & 3.00 & 3.00 & 3.00 & \\
\hline Maximum & 5.00 & 5.00 & 5.00 & \\
\hline Sum & 1449.00 & 1457.00 & 1435.00 & \\
\hline
\end{tabular}

Sumber: Data primer yang diolah, 2020 
Berdasarkan tabel 3 diatas, dapat diketahui bahwa variabel Politik Organisasi dengan jumlah data 314 memiliki nilai rata-rata 4,6146. Nilai rata-rata minimum sebesar 3,00 dan nilai maksimum 5,00 dengan total 1449,00 dan standar deviasi 0,51300. Berikutnya variabel Komitmen Organisasional dengan jumlah data 314 memiliki nilai rata-rata 4,6401. Nilai rata-rata minimum sebesar 3,00 dan nilai maksimum 5,00 dengan total 1457,96 dan standar deviasi 0,50027. Sedangkan untuk variabel Organisational Citizenship Behavior dengan jumlah data 134 memiliki nilai rata-rata 4,5701. Nilai rata-rata minimum sebesar 3,00 dan nilai maksimum 5,00 dengan total 1435,.00 dan standar deviasi 0.52709

\section{Hasil Uji Kualitas Data}

\section{Hasil Uji Validitas}

Untuk mengetahui valid/sah tidaknya sebuah kuesioner, maka perlu dilakukan uji validitas Uji ini dilakukan dengan cara menguji kolerasi antara skor item dengan skor total masing-masing variabel, dengan menggunakan Pearson Correlation. Butir-butir pernyataan dalam kuisioner dianggap sah atau valid apabila tingkat signifikansi yang dihasilkan dibawah 0,05 .

(1) Politik Organisasi $\left(\mathrm{X}_{1}\right)$

Hasil uji validitas untuk variabel Politik Organisasi (X1) dengan menggunakan koefisien korelasi Pearson diuraikan dalam tabel berikut ini :

Tabel 4: Uji Validitas Politik Organisasi (X1)

\begin{tabular}{|c|c|c|c|c|}
\hline $\begin{array}{c}\text { Butir } \\
\text { Pernyataan }\end{array}$ & $\begin{array}{r}\text { Pearson } \\
\text { Corel } \\
\text { ation }\end{array}$ & $\begin{array}{c}\text { Sig (2- } \\
\text { Tailed } \\
\text { ) }\end{array}$ & $\begin{array}{c}\text { Keteran } \\
\text { gan }\end{array}$ & \\
\hline \multirow{14}{*}{$\mathrm{X} 1$} & PO1 & $0.142 * *$ & 0.012 & Valid \\
\hline & $\mathrm{PO} 2$ & $0.533 * *$ & 0.000 & Valid \\
\hline & PO3 & $0.624 * *$ & 0.000 & Valid \\
\hline & PO4 & $0.258^{* *}$ & 0.000 & Valid \\
\hline & PO5 & $0.352 * *$ & 0.000 & Valid \\
\hline & PO6 & $0.119 * *$ & 0.034 & Valid \\
\hline & PO7 & $0.499 * *$ & 0.000 & Valid \\
\hline & PO8 & $0.596^{* *}$ & 0.000 & Valid \\
\hline & PO9 & $0.502 * *$ & 0.000 & Valid \\
\hline & PO10 & $0.624 * *$ & 0.000 & Valid \\
\hline & PO11 & $0.343 * *$ & 0.000 & Valid \\
\hline & PO12 & $0.465 * *$ & 0.000 & Valid \\
\hline & PO13 & $0.504 * *$ & 0.000 & Valid \\
\hline & PO14 & $0.533^{* *}$ & 0.000 & Valid \\
\hline
\end{tabular}




\begin{tabular}{|c|c|c|c|}
\hline PO15 & $0.603^{* *}$ & 0.000 & Valid \\
\hline PO16 & $0.505^{* *}$ & 0.000 & Valid \\
\hline PO17 & $0.477^{* *}$ & 0.000 & Valid \\
\hline PO18 & $0.227^{* *}$ & 0.013 & Valid \\
\hline PO19 & $0.242^{* *}$ & 0.000 & Valid \\
\hline
\end{tabular}

Sumber: Data primer yang diolah, 2020

Dari tabel 4 diatas dapat disimpulkan bahwa 19 butir pernyataan dalam kuisioner memiliki nilai signifikansi lebih kecil dari 0.05 sehingga dapat disimpulkan bahwa semua item pernyataan dalam penelitian tersebut valid.

\section{Variabel Komitmen Organisasional $\left(\mathbf{X}_{2}\right)$}

Hasil pengujian validitas variabel Komitmen Organisational $\left(\mathrm{X}_{2}\right)$ dengan menggunakan koefisien korelasi Pearson diuraikan dalam tabel berikut ini :

Tabel 5: Komitmen Organisasional $\left(\mathrm{X}_{2}\right)$

\begin{tabular}{|c|c|c|c|c|}
\hline $\begin{array}{c}\text { Butir } \\
\text { Pernyataa } \\
\mathbf{n}\end{array}$ & $\begin{array}{r}\text { Pearson } \\
\text { Corel } \\
\text { ation }\end{array}$ & $\begin{array}{c}\text { Sig (2- } \\
\text { Tailed }\end{array}$ & $\begin{array}{r}\text { Keteran } \\
\text { gan }\end{array}$ & \\
\hline X2 & KO1 & $0.279 * *$ & 0.000 & Valid \\
\hline & KO2 & $0.412^{*}$ & 0.021 & Valid \\
\hline & KO3 & $0.213^{* *}$ & 0.000 & Valid \\
\hline & KO4 & $0.711^{*}$ & 0.027 & Valid \\
\hline & KO5 & $0.533^{*}$ & 0.000 & Valid \\
\hline & KO6 & $0.502 * *$ & 0.000 & Valid \\
\hline & KO7 & $0.409 * *$ & 0.000 & Valid \\
\hline & KO8 & $0.174 * *$ & 0.000 & Valid \\
\hline & KO9 & $0.399 * *$ & 0.000 & Valid \\
\hline & KO10 & $0.711^{* *}$ & 0.000 & Valid \\
\hline
\end{tabular}

Sumber: Data primer yang diolah, 2020

Merujuk pada tabel 5 diketahui bahwa 10 butir pernyataan dalam kuesioner memiliki nilai signifikansi lebih kecil dari 0.05 sehingga dapat diambil kesimpulan bahwa seluruh item pernyataan dalam penelitian tersebut valid.

\section{(3) Variabel Organizational Citizenship Behavior (Y)}

Hasil pengujian validitas variabel Organizational Citizenship Behavior (Y) dengan menggunakan koefisien korelasi Pearson diilustrasikan dalam tabel berikut ini: 
Tabel 6 : Uji Validitas Organizational Citizenship Behavior (Y)

\begin{tabular}{|c|c|c|c|c|}
\hline $\begin{array}{c}\text { Butir } \\
\text { Pernyataan }\end{array}$ & $\begin{array}{r}\text { Pearson } \\
\text { Corel } \\
\text { ation }\end{array}$ & $\begin{array}{c}\text { Sig (2- } \\
\text { Tailed) }\end{array}$ & $\begin{array}{r}\text { Keteran } \\
\text { gan }\end{array}$ & \\
\hline & OCB1 & $0.347^{* *}$ & 0.000 & Valid \\
\hline & OCB2 & $0.397^{* *}$ & 0.000 & Valid \\
\hline & OCB3 & $0.585^{* *}$ & 0.000 & Valid \\
\hline & OCB4 & $0.557^{* *}$ & 0.000 & Valid \\
\hline & OCB5 & $0.547^{* *}$ & 0.000 & Valid \\
\hline & OCB6 & $0.547^{* *}$ & 0.000 & Valid \\
\hline & OCB7 & $0.363^{* *}$ & 0.000 & Valid \\
\hline & OCB8 & $0.555^{* *}$ & 0.000 & Valid \\
\hline & OCB9 & $0.161^{* *}$ & 0.000 & Valid \\
\hline & OCB10 & $0.585^{* *}$ & 0.000 & Valid \\
\hline
\end{tabular}

Sumber : Data primer yang diolah, 2020

Dari tabel 6 diketahui bahwa 10 item pernyataan dalam kuesioner memiliki nilai signifikansi lebih kecil dari 0.05 sehingga dapat diambil kesimpulan bahwa seluruh item pernyataan dalam penelitian tersebut valid.

\section{Hasil Uji Reliabilitas}

Sebuah kuesioner merupakan pengejawantahan indikator-indikator dari sebuah variabel atau konstruk. Untuk itu diperlukan alat untuk mengukur Uji reliabilitas yang dilakukan untuk menguji konsistensi jawaban dari responden melalui pernyataan yang diberikan. Dengan menggunakan metode statistik Cronbach Alpha dengan taraf signifikansi yang digunakan lebih dari $(>) 0,6$. berikut ini hasil dari pengujian reliabilitas dari variabel-variabel dalam penelitian ini:

\section{Tabel 7: Hasil Uji Reliabilitas}

\begin{tabular}{|l|c|c|}
\hline \multicolumn{1}{|c|}{ Variabel } & $\begin{array}{c}\text { Cronbach's } \\
\text { Alpha }\end{array}$ & Keterangan \\
\hline Politik Organisasi (X1) & 0.772 & Reliabel \\
\hline Komitmen Organisasional (X2) & 0.680 & Reliabel \\
\hline Organizational Citizenship Behaviour $(\mathrm{Y})$ & 0.777 & Reliabel \\
\hline
\end{tabular}

Sumber: Data primer yang diolah, 2020 
Tabel 7 menggambarkan bahwa variabel Politik Organisasi, Komitmen Organisasional dan Organizational Citizenship Behavior mempunyai nilai Cronbach's Alpha lebih besar dari 0,6. Hal ini menegaskan bahwa butir - butir pernyataan dalam penelitian ini bersifat reliabel. Sehingga semua pernyataan yang digunakan akan mampu memperoleh jawaban yang relatif sama dengan jawaban yang sebelumnya.

\section{Hasil Uji Asumsi Klasik}

\section{Hasil Uji Normalitas}

Untuk mengetahui apakah data yang dipergunakan dalam sebuah model regresi, menghasilkan error yang berdistribusi normal ataukah tidak maka digunakan uji normalitas. Hasil uji normalitas data ditampilkan dengan menggunakan grafik Normal P-P Plot of Regression Standardized Residual yang dapat dilihat pada gambar berikut ini :

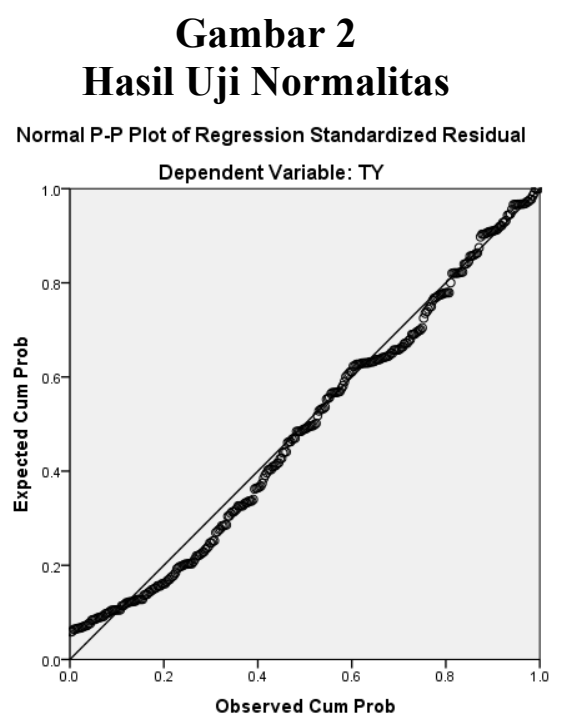

Sumber: Data primer yang diolah, 2020

Berpedoman pada Gambar 1 menampakkan bahwa titik-titik menyebar disekitar garis diagonal, serta arah penyebarannya mengikuti arah garis diagonal. Hal ini menunjukkan bahwa model regresi layak dipakai karena memenuhi asumsi normalitas.

\section{Hasil Uji Multikolinieritas}

Untuk melihat ada atau tidaknya korelasi yang tinggi antara variabel-variabel independen dalam suatu model regresi linier berganda, maka perlu dilakukan uji multikolinieritas. Jika dalam hasil pengujian ditemukan korelasi yang tinggi diantara variabel-variabel independennya, maka hubungan antara variabel independen terhadap variabel dependennya akan menjadi terganggu. Uji multikolinieritas dapat dilihat dari nilai Tolerance dan nilai VIF (Variance Inflation Factor) yang dihasilkan. Jika nilai VIF tidak lebih dari 10 dan nilai tolerance tidak kurang dari 0,1 maka model dapat dikatakan terbebas dari multikolinieritas (Sunjoyo, dkk. 2013). Adapun hasil pengujian multikolinieritas disajikan pada tabel berikut ini:

\section{Tabel 8: Hasil Uji Multikolinieritas}

\begin{tabular}{|l|r|r|}
\hline Coefficients $^{\mathbf{a}}$ & \multicolumn{3}{|c|}{ Collinearity Statistics } \\
\hline \multirow{2}{*}{ Model } & Tolerance & VIF \\
\hline Politik Organisasi & .992 & \\
\hline Komitmen Organisasional & .992 & 1.008 \\
\hline
\end{tabular}

a. Dependent Variable: Organisational Citizenship Behaviour

Sumber: Data primer yang diolah, 2020 
Berdasarkan tabel 8 dapat dilihat bahwa variabel Politik Organisasi dan Komitmen Organisasional memiliki nilai tolerance diatas 0,1 dan VIF lebih kecil dari 10. Ini berarti bahwa model persamaan regresi tidak menunjukkan gejala multikolinieritas sehingga data dapat digunakan dalam penelitian ini.

\section{Hasil Uji Heteroskedastisitas}

Untuk melihat apakah terdapat ketidaksamaan varians pada residual dari satu pengamatan ke pengamatan yang lain maka perlu dilakukan uji heteroskedastisitas. Uji heteroskedastisitas ini dilakukan dengan menggunakan metode scatter plot yang mendeteksi penyebaran titik-titik. Jika penyebaran titik-titik yang ditimbulkan berbentuk secara acak, tidak membentuk sebuah pola tertentu serta arah penyebarannya berada diatas maupun dibawah angka 0 pada sumbu Y, maka bisa dipastikan bahwa tidak terjadi gejala heteroskedastisitas. Hasil uji heteroskedastisitas dapat dilihat dalam gambar berikut ini :

\section{Gambar 2}

\section{Hasil Uji Heteroskedastisitas}

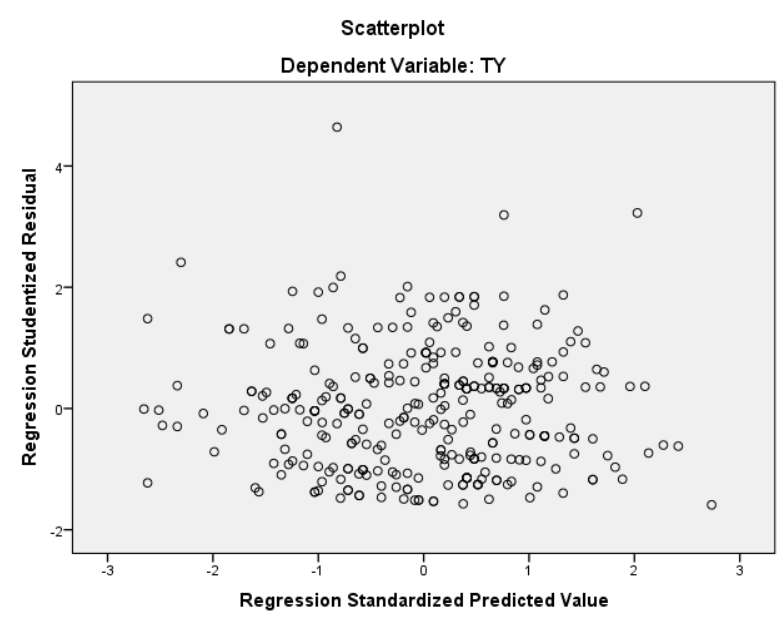

Sumber: Data primer yang diolah, 2020

\section{Hasil Uji Hipotesis}

\section{Analisis Regresi Linier Berganda}

Setelah melakukanl uji asumsi klasik yang merupakan prasyarat sebelum melakukan uji regresi atau uji hipotesis dan secara keseluruhan hasilnya menunjukkan model regresi yang memenuhi standar asumsi klasik, tahap berikutnya yaitu melakukan uji regresi, melihat hasilnya kemudian melakukan evaluasi dan memberikan interpretasi atas model regresi berganda yang dihasilkan. Berikut hasil uji regresi ditampilkan dalam tabel model persamaan regresi seperti dibawah ini:

Tabel 9: Model Persamaan Regresi

\begin{tabular}{|c|c|c|c|c|c|c|}
\hline \multicolumn{2}{|c|}{ Coefficients $^{\mathrm{a}}$} \\
\multirow{2}{*}{ Model } & \multicolumn{2}{|c|}{$\begin{array}{c}\text { Unstandardized } \\
\text { Coefficients }\end{array}$} & $\begin{array}{c}\text { Standardized } \\
\text { Coefficients }\end{array}$ & \multirow{2}{*}{ t } & \multirow{2}{*}{ Sig. } \\
\cline { 3 - 7 } & & B & Std. Error & Beta & & \\
\hline \multirow{2}{*}{1} & (Constant) & 7.122 & .415 & & 17.174 & .000 \\
\hline & PO & .563 & .068 & .023 & .454 & .650 \\
\hline & KO & -599 & .068 & -.448 & -8.793 & .000 \\
\hline
\end{tabular}

a. Dependent Variable: OCB

Sumber: Data primer yang diolah, 2020 
Berdasarkan Tabel 9 diatas, maka persamaan regresi yang terbentuk pada uji regresi ini adalah:

$\mathrm{Y}=7.122+0.563 \mathrm{X}_{1}-0.599 \mathrm{X}_{2}+\mathrm{e}$

Model tersebut dapat diinterpretasikan sebagai berikut:

1. Nilai konstanta adalah 7.122 ini menunjukkan bahwa, jika variabel independen (Politik Organisasi dan Komitmen Organisasisional) bernilai (0), maka nilai variabel dependen (Organizational Citizenship Behavior) sebesar 7.122 satuan.

2. Koefisien regresi Politik Organisasi $\left(b_{1}\right)$ adalah 0.563 dan bertanda positif. Hal ini mengandung arti bahwa, nilai variabel Y akan mengalami kenaikan sebesar 0.563 apabila nilai variabel $\mathrm{X}_{1}$ mengalami kenaikan satu satuan dan variabel independen lainnya bernilai tetap. Koefisien bertanda positif menunjukkan adanya hubungan yang searah antara variabel Politik Organisasi dengan variabel Organizational Citizenship Behavior (Y). semakin tinggi Politik Organisasi, maka semakin tinggi pula Organisational Citizenship Behaviornya.

3. Koefisien regresi Komitmen Organisasional $\left(b_{2}\right)$ adalah -0.599 dan bertanda negatif. Hal ini berarti, nilai variabel $\mathrm{Y}$ akan mengalami penurunan sebesar 0.599 apabila nilai variabel $\mathrm{X}_{2}$ mengalami kenaikan satu satuan dan variabel independen lainnya bernilai tetap. Koefisien bertanda negatif menunjukkan adanya hubungan yang berlawanan arah antara Komitmen Organisasional $\left(\mathrm{X}_{2}\right)$ dengan variabel Organizational Citizenship Behavior (Y). semakin tinggi Komitmen Organisasional maka Organizational Citizenship Behavio-nya pun akan semakin menurun.

\section{Uji $\mathbf{R}^{2}$ (Koefisien Determinasi)}

Untuk mengetahui seberapa besar kemampuan variabel independen untuk menjelaskan variabel dependen maka dilakukan uji koefisien determinasi atau uji $\mathrm{R}^{2}$.

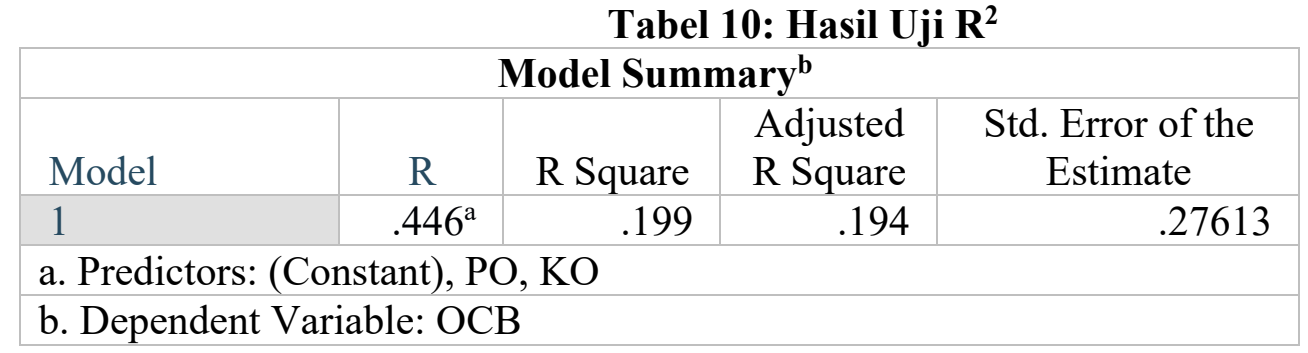

Sumber: Data primer yang diolah, 2020

Dari tabel 10 terlihat bahwa angka $\mathrm{R}$ sebesar 0.446 yang menunjukkan bahwa hubungan antara Organizational Citizenship Behavior dengan kedua variabel independennya cukup kuat karena berada pada angka 0,4. Sedangkan nilai $\mathrm{R}$ square sebesar 0,199 atau 19,9\% ini menunjukkan bahwa variabel Organizational Citizenship Behavior dapat dijelaskan oleh variabel Politik Organisasi dan Komitmen Organisasional sebesar 19,9\% sedangkan sisanya 80,1\% dapat dijelaskan dengan variabel lain yang tidak terdapat pada penelitian ini.

\section{Hasil Uji F}

Uji $\mathrm{F}$ atau uji simultan ini dilakukan untuk mengetahui apakah variabel-variabel independen secara serempak (simultan) mempengaruhi variabel dependen secara signifikan. Pengujian simultan ini dilakukan dengan membandingkan antara nilai signifikan $\mathrm{F}$ dengan nilai signifikan yang digunakan yaitu pada level $\alpha=0,05(5 \%)$. 
Tabel 11 : Hasil Uji F

\begin{tabular}{|c|c|c|c|c|c|c|}
\hline \multicolumn{7}{|c|}{ ANOVA $^{\mathrm{a}}$} \\
\hline \multicolumn{2}{|c|}{ Model } & $\begin{array}{l}\text { Sum of } \\
\text { Squares }\end{array}$ & df & Mean Square & $\mathrm{F}$ & Sig. \\
\hline \multirow[t]{3}{*}{1} & Regression & 5.904 & 2 & 2.952 & $\begin{array}{r}38.71 \\
7\end{array}$ & $.000^{\mathrm{b}}$ \\
\hline & Residual & 23.173 & 311 & .076 & & \\
\hline & Total & 29.617 & 313 & & & \\
\hline \multicolumn{7}{|c|}{ a. Dependent Variable: OCB } \\
\hline \multicolumn{7}{|c|}{ b. Predictors: (Constant), PO, KO } \\
\hline
\end{tabular}

Sumber : Data primer yang diolah, 2020

Berdasarkan tabel 11 Anova sig sebesar 0.000 yang berarti bahwa secara simultan seluruh variable independen : Politik Organisasi $\left(\mathrm{X}_{1}\right)$ dan Komitmen Organisasional $\left(\mathrm{X}_{2}\right)$ berpengaruh signifikan terhadap variabel dependen organisational Citizenship Behaviour (Y) Dengan demikian, model yang digunakan dalam penelitian ini dapat digunakan untuk menjelaskan pengaruh Politik Organisasi dan Komitmen Organisasional terhadap Organisational Citizenship Behaviour Dengan demikian maka : H3 diterima sehingga dapat dikatakan bahwa Politik Organisasi dan Komitmen Organisasional secara simultan berpengaruh signifikan terhadap Organisational Citizenship Behavior.

\section{Hasil Uji Parsial (Uji t)}

Uji parsial atau uji t dilakukan untuk mengetahui pengaruh tiap-tiap variabel independen terhadap variabel dependen. Uji t dilakukan dengan melihat seberapa besar nilai signifikansi t hitung, jika nilai signifikansi $<$ dari 0,05 maka dapat diambil kesimpulan bahwa variabel independen tersebut mempunyai pengaruh terhadap variabel dependen.

Melalui statistik uji-t yang terdiri dari Politik Organisasi $\left(\mathrm{X}_{1}\right)$ dan Komitmen Organisasional $\left(\mathrm{X}_{2}\right)$ dapat diketahui secara parsial pengaruhnya terhadap Organizational Citizenship Behaviour (Y).

(a) Pengujian Hipotesis Pertama $\left(\mathrm{H}_{1}\right)$

Tabel 8 menunjukkan bahwa variabel Politik Organisasi memiliki tingkat signifikansi sebesar 0,650

yaitu lebih kecil dari 0,05. Hal ini berarti H1 ditolak sehingga bisa disimpulkan bahwa Politik Organisasi tidak berpengaruh signifikan terhadap Organizational Citizenship Behavior.

(b) Pengaruh Hipotesis Kedua $\left(\mathrm{H}_{2}\right)$

Tabel 8 menunjukkan bahwa variabel Komitmen Organisasional memiliki tingkat signifikansi sebesar 0,000 yaitu lebih kecil dari 0,05. Hal ini berarti $\mathbf{H 2}$ diterima sehingga dapat dikatakan bahwa Komitmen Organisasional berpengaruh signifikan terhadap Organizational Citizenship Behavior. Nilai t yang bernilai -8.793 menunjukkan pengaruh yang diberikan bersifat negatif terhadap variabel dependen.

\section{Pembahasan}

\section{Pengaruh Politik Organisasi dan Komitmen Organisasional Secara Simultan Terhadap Organizational Citizenship Behavior}

Dari hasil penelitian dapat diketahui bahwa Politik Organisasi dan Komitmen Organisasional secara simultan berpengaruh signifikan terhadap Organizational Citizenship Behavior para pegawai ASN di Lingkup SOPD kabupaten Boalemo. Hal ini dapat dimaknai bahwa Politik Organisasi dan Komitmen 
Organisasional secara signifikan akan mempengaruhi Organizational Citizenship Behavior. Politik organisasi yang berlangsung pada taraf sewajarnya dan adanya komitmen organisasi yang tinggi akan mendorong munculnya perilaku para Aparatur Sipil Negara yang secara sadar dan sukarela memberikan kontribusi dan sumbangsihnya berupa tenaga maupun pemikirannya secara semaksimal mungkin bahkan sampai melebihi dari kewajiban-kewajiban formal yang menjadi beban mereka. Jika memperhatikan nilai koefisien yang dihasilkan dalam uji F yakni 5.904 atau 59,04\% dan nilai signifikansi diangka 0,000 bisa disimpulkan bahwa pengaruhnya cukup kuat dan signifikan.

Dari penelitian ini diperoleh hasil jawaban mayoritas dari responden yakni Sangat Setuju dan Setuju untuk rata-rata pernyataan dalam kuisioner. Ini mengindikasikan bahwa praktik-praktik politik organisasi yang terjadi serta kuat ataupun lemahnya komitmen organisasional dari masing-masing individu mempunyai korelasi yang erat dengan Organizational Citizenship Behavior dari masing-masing pegawai. Dimensidimensi Organizational Citizenship Behavior menurut Luthans, (2006) yang menjadi patokan dalam penelitian yakni dimensi altruisme, kesungguhan, kepentingan umum, sikap positif, sopan ini telah mereka implementasikan dalam kehidupan organisasi (Cheng \& Fang, 2008). Sebagai contoh, untuk sikap altruisme mereka wujudkan dengan sikap yang rela dan mau berbagi peran dengan sesama teman dengan menggantikan tugas-tugas dari rekan kerja mereka yang sedang absen atau lagi mengambil cuti, atau melalui tindakan yang tidak segan untuk membantu rekan kerja mereka untuk mengoperasikan peralatan-peralatan kantor yang belum mereka kuasai, contohnya seperti komputer, dll. Sikap berikutnya adalah adanya kesungguhan dari para ASN akan tugas dan tanggung jawabnya dalam pekerjaannya masing-masing sehingga selalu termotivasi untuk menyelesaikan tugas dan tanggung jawab yang dibebankan dengan sebaik-baiknya. Termasuk dalam hal ini secara bijak memahami dan menaati jam kerja yang telah ditentukan, baik sehubungan dengan jam kedatangan maupun jam kepulangan. Para ASN ini juga selalu berusaha menjaga kepentingan umum dengan cara menjalin komunikasi dan hubungan yang baik dengan sesama rekan kerja. Mereka juga senantiasa bersikap sportif dengan berusaha menjalankan tugas dengan ikhlas dan tanpa komplain dan selalu berusaha menerima setiap kebijakan baru yang diberlakukan organisasi. Kebebasan berpendapat juga dijunjung tinggi dengan menghargai setiap pendapat dari rekan kerja, disamping itu mereka juga selalu berusaha menumbuhkan empati terhadap sesama rekan kerja maupun pimpinan sehingga selalu berupaya secara maksimal membantu memikirkan kemajuan organisasi.

\section{Pengaruh Variabel Politik Organisasi Terhadap Organizational Citizenship Behavior}

Dari hasil penelitian dapat diketahui bahwa Politik Organisasi tidak berpengaruh positif dan signifikan terhadap Organizational Citizenship Behavior Aparatur Sipil Negara dalam lingkup Satuan Organisasi Perangkat Daerah kabupaten Boalemo. Hal ini kontras dengan hasil uji $\mathrm{F}$ atau uji simultan yang menghasilkan kesimpulan bahwa kedua variabel independen yakni Politik Organisasi bersama-sama dengan variabel Komitmen Organisasional berpengaruh signifikan terhadap Organizational Citizenship Behavior (OCB). Uji parsial untuk Politik Organisasi menghasilkan angka signifikansi sebesar 0,065>0,000 yang berarti hasil kesimpulannya tidak berpengaruh terhadap variabel dependen . Kesimpulan lain juga diambil dengan membandingkan nilat $\mathrm{t}$-hitung dan $\mathrm{t} \mathrm{t}_{\mathrm{abel}}$. Nilai $\mathrm{t}$-hitung yang dihasilkan sebesar $0,563<\mathrm{t}-\mathrm{t}_{\text {abel }}$ yang juga menghasilkan kesimpulan yang sama yakni tidak adanya pengaruh variabel Politik Organisasi (X1) terhadap Organizational Citizenship Behavior (Y).

Hasil penelitian ini bukan sesuatu hal yang baru atau mengejutkan. Beberapa penelitian sejenis yang meneliti hubungan variabel dependen Organizational Citizenship Behavior (OCB) dengan salah satu variabel independen yakni Politik Organisasi menghasilkan kesimpulan bahwa tidak ada pengaruh Politik Organisasi terhadap Organizational Citizenship Behavior. Salah satu contohnya yakni penelitian yang 
dilakukan oleh Hendra Gunawan Dan T. Elisabeth Cintya Santosa (2012) dengan judul penelitian “ Politik Organisasi dan Dampaknya Terhadap Komitmen Organisasi, Kepuasan Kerja, Kinerja dan Organizational Citizenship Behavior (OCB) (Luthans, 2006) Penelitian ini menghasilkan kesimpulan bahwa Politik Organisasi mempunyai hubungan secara positif dan signifikan dengan Komitmen Organisasi, Kepuasan Kerja, Kinerja tetapi tidak berpengaruh terhadap Organizational Citizenship Behavior (OCB).

Sebelumnya dalam penjelasan dibagian tinjauan pustaka peneliti memprediksi kemungkinan adanya bias penelitian yang disebabkan oleh adanya stigma bahwa karakter ASN atau birokrat yang cenderung kaku dan tertutup sehingga ada kemungkinan timbul resistensi dari para responden untuk mendapatkan data yang valid. Kalaupun memberikan jawaban bisa jadi ada beberapa dari responden yang menjawab tidak jujur karena alasan yang bersifat pribadi, karena takut dengan pimpinan atau alasan personal lainnya, ada yang menjawab sekedarnya saja, atau bahkan ikut-ikutan dengan rekannya. Hal ini menurut dugaan peneliti bisa jadi ada hubungannya dengan kesimpulan akhir yang didapatkan tentunya merujuk kepada hasil olahan data. Kemungkinan dugaan ini tentu saja tidak bersifat mutlak untuk dijadikan argumen yang bisa dijadikan dasar sebelum dilakukan penelitian-penelitian lebih lanjut sehubungan dengan hal ini.

Dimensi-dimensi Politik Organisasi berupa organizational practises \& policies (praktek dan kebijakan organisasi), colleagues behavior (perilaku rekan kerja), serta go along to get ahead (untuk terus menjadi tujuan)(Chang \&Fang, 2008) meskipun dalam perspektif yang negatif jangan menjadi penghalang para pegawai untuk tetap berpegang teguh pada nilai-nilai positif yang tetap memunculkan motivasi yang tinggi untuk melaksanakan kewajiban dan tugas dengan sebaik-baiknya. dan sebaliknya jangan sampai menjadi pemicu untuk menghalangi terciptanya Organizational Citizenship Behavior (OCB) yang baik. Untuk memupuk kerjasama dan integritas dari para pegawai ASN tidak mudah dan butuh proses yang panjang agar bisa menjadi budaya organisasi. ketika budaya organisasi yang baik sudah terbina maka akan tumbuh tingkat kepercayaan diantara sesama rekan kerja maupun dengan pimpinan. Hal ini pada gilirannya akan mempersempit ruang gerak bagi berkembangnya praktik-praktik organisasi yang tidak sehat dan menekan laju "tingkat berpolitik" para pegawai (Robbin, 2013)

Mayoritas jawaban responden "Setuju" dan "Sangat Setuju" bahkan untuk pernyataan yang yang bermakna negatif menguatkan dugaan adanya bias yang terjadi. Apakah responden menjawab jujur sesuai dengan nuraninya atau ikut-ikutan dengan temannya saja, asal menjawab, atau alasan takut kepada pimpinan, atau alasan yang bersifat pribadi lainnya. Tapi sekali lagi ini tentu perlu penelitian lebih lanjut untuk menjawab pertanyaaan-pertanyaan ini.

\section{Pengaruh Komitmen Organisastional Terhadap Organizational Citizenship Behavior}

Hasil uji parsial pengaruh Komitmen Organisational terhadap Organizational Citizenship Behavior menunjukkan hasil dengan angka koefisien regresi yang bernilai negatif sebesar -.599. Ini dapat dimaknai bahwa Komitmen Organisasional berpengaruh negatif dan signifikan terhadap Organizational Citizenship Behavior para pegawai ASN di lingkup SOPD Kabupaten Boalemo. Dengan kata lain jika variabel Komitmen Organisasional naik sebanyak satu satuan dan variabel lainnya bernilai tetap, maka variabel Organizational Citizenship Behavior justru akan mengalami penurunan sebesar -0.599. atau semakin tinggi Komitmen Organisasional maka semakin rendah pula Organizational Citizenship Behavior dari para pegawai ASN tersebut. Hubungan yang negatif dan signifikan ini juga pernah didapatkan dari hasil penelitian Winda Wahyuningsih, Ninik Lukiana \&Jesi Irwanto dengan topik penelitian “ Pengaruh 
Kepuasan Kerja dan Komitmen Organisasi Terhadap Organizational Citizenship Behavior (studi kasus pada karyawan Koperasi Serambi Dana Lumajang) Dalam penelitian terhadap 32 orang karyawan ini didapatkan hasil bahwa walaupun variabel independen lain yaitu Kepuasan Kerja berpengaruh positif dan signifikan terhadap Organizational Citizenship Behavior (OCB), tetapi sebaliknya variabel Komitmen Organisasi berpengaruh negatif terhadap Organizational Citizenship Behavior (Winda, dkk, 2014)

Hasil negatif yang didapatkan ini merupakan sebuah hubungan yang unik tapi tetap dimungkinkan dalam sebuah penelitian, segala kemungkinan bisa saja terjadi. apalagi sejak diawal penulis sudah sedikit menyentil tentang beberapa kendala yang mungkin dihadapi jika berhubungan dengan responden dengan latar belakang sebagai seorang ASN. Komitmen organisasional seorang pegawai mengindikasikan sebuah spirit, sebuah elan vital, sebuah daya hidup dimana seorang pegawai mengidentifikasikan keterlibatan dirinya menjadi bagian dari sebuah organisasi. Fondasi dari komitmen organisasional terbangun atas dasar adanya rasa saling mempercayai dari para pegawai terhadap nilai-nilai dari organisasi. Sejauh mana kerelaan dari para pegawai dalam membantu mewujudkan tujuan-tujuan organisasi dan terbangunnya kesetiaan untuk tetap menjadi dari organisasi. Sejatinya komitmen organisasional menjadi pemilcu terbentuknya "sense of belonging" atau rasa memiliki dari para pegawai terhadap organisasi tempatnya bekerja.

Distribusi jawaban responden yang mayoritas menjawab "Setuju" dan "Sangat Setuju" untuk setiap butir pernyataan sehubungan dengan komitmen organisasional menyiratkan bahwa komitmen organisasional dari para pegawai ASN dilingkup Satuan Kerja Perangkat Daerah (SOPD) Kabupaten Boalemo tergolong cukup tinggi. Indikator-indikator pengukuran variabel Komitmen Organisasional seperti affective commitment (komitmen afektif), continuance commitment (komitmen berkelanjutan) serta normative commitment (komitmen normatif) sudah mencerminkan sejauh mana para pegawai ASN dilingkup Satuan Organisasi Perangkat Daerah dilingkup Kabupaten Boalemo sudah merasa terikat pada organisasinya (Luthans, 2006). mengambil contoh untuk indikator affective commitment, para pegawai ASN ini seolah sudah menjadi bagian dari organisasi, merasakan seolah-olah permasalahan organisasi adalah permasalahan mereka sendiri serta sudah memiliki rasa keterikatan yang kuat terhadap organisasinya. dari segi continuance commitment dapat dilihat bahwa para ASN telah memiliki komitmen untuk tetap bertahan dan bersamasama dengan organisasi dalam waktu yang lama, karena mereka merasa bekerja dalam organisasi ditempat mereka itu bukan hanya kebutuhan mereka tetapi melainkan sekaligus keinginan mereka. meninggalkan organisasi hanya akan membutuhkan pengorbanan pribadi yang lebih besar dan mungkin diorganisasi yang baru jika mereka pindah belum tentu akan mendapatkan benefit seperti yang mereka daripada dtempat kerja mereka yang lama. Dari aspek normative commitment, para ASN merasa bahwa berpindah dari satu organisasi ke organisasi yang lain bukanlah sebuah tindakan yang etis dan loyalitas adalah sebuah hal yang sangat penting karena itu merupakan sebuah kewajiban moral yang harus dijunjung tinggi oleh para pegawai. Karena itu meskipun mendapatkan iming-iming jabatan posisi yang bagus ditempat yang baru tidak akan melunturkan kesetiaannya untuk tetap bertahan bersama dengan organisasi yang selama ini membesarkannya. Tanpa bermaksud menambahkan bahwa hasil penelitian yang kontras seperti yang diuraikan tema penelitian ini diatas boleh jadi disebabkan karena adanya bias yang terjadi, peneliti juga mengharapkan dipenelitian selanjutnya untuk topik yang masih dan sehubungan dengan politik organisasi, komitmen organisasional dan Organizational Citizenship Behavior akan melibatkan partisipasi responden yang lebih banyak agar hasil yang lebih presisi dan lebih merepresentasikan aspirasi dari populasi yang diteliti. 


\section{KESIMPULAN DAN SARAN}

\section{Kesimpulan}

Berdasarkan hasil penelitian dan hasil olah data yang diuraikan pada pembahasan maka dapat disimpulkan bahwa Secara simultan Politik Organisasi (X1) dan Komitmen Organisasional (X2) berpengaruh positif dan signifikan terhadap Organizational Citizenship Behavior (Y) para pegawai ASN dalam lingkup SOPD Kabupaten Boalemo. Nilai signifikansi sebesar 0,000 serta nilai $f_{\text {hitung }}>\mathrm{f}_{\text {tabel }}$ yang dihasilkan sehingga bisa disimpulkan menunjukkan bahwa ada pengaruh kedua variabel independen terhadap variabel dependen. nilai koefisien determinasi $\left(\mathrm{R}^{2)}\right.$ yang dihasilkan juga menunjukkan bahwa ada korelasi yang kuat antara variabel independen dan variabel dependen. Secara parsial variabel Politik Organisasi (X1) tidak berpengaruh terhadap Organizational Citizenship Behavior (Y) para pegawai ASN dalam lingkup SOPD Kabupaten Boalemo. ini bisa dilhat dari nilai koefisien regresi yang dihasilkan yang menghasilkan nilai signifikansi sebesar 0,65>0,000 dan juga nilai $t$ hitung yang dihasilkan sebesar 0,563> lebih besar dari $t$ tabel yaitu 0,454. Secara parsial Komitmen Organisasional (X2) berpengaruh negatif dan signifikan terhadap Organizational Citizenship Behavior (Y). Nilai signifikansi dengan angka 0,000 menunjukkan adanya pengaruh variabel independen terhadap variabel dependen. nilai koefisien regresi yang negatif menunjukkan korelasi yang negatif, artinya semakin tinggi Komitmen Organisasional maka akan semakin rendah Organizational Citizenship Behavior dari para pegawai ASN dilingkup Kabupaten Boalemo, dan begitupun sebaliknya.

\section{Saran}

Bagi pihak instansi dimasing-masing Satuan Organisasi Perangkat Daerah (SOPD) Hasil dari penelitian ini diharapkan bisa djadikan bahan pertimbangan dalam upaya mengatasi masalah-masalah yang timbul sehubungan dengan Organizatioaal Citizenship Behavior (OCB) para ASN dalam organisasi mereka. Selain itu bagian personalia (SDM) harus memberikan perhatian khusus pada komitmen organisasional pegawai. Organisasi harus menginisiasi beberapa kebijakan-kebijakan baru sehubungan dengan sistem reward yang lebih baik ketimbang memperketat aturan tentang punishment. Sistem reward yang lebih baik yang dimaksudkan disini adalah sistem reward yang bukan semata-mata berbentuk materi, tapi lebih kepada yang bersifat non-material, seperti merit sistem yang lebih baik, penegakan pemberian promosi yang adil sesuai dengan aturan yang berlaku dan berupaya menciptakan iklim organisasi yang baik sehingga pada gilirannya akan menciptakan kenyamanan bagi para pegawai. Jika pegawai ASN sudah merasa nyaman maka dengan sendirinya pegawai akan merasa bahagia dan bangga telah menjadi bagian dari organisasi. Dengan demikian akan tercipta komitmen organisasional akan semakin terbentuk dan pada gilirannya menciptakan Organizational Citizenship Behavior (OCB). Politik organisasi meskipun dalam hasil penelitian terbukti tidak berpengaruh terhadap Organizational Citizenship Behavior (OCB) tetap perlu menjadi perhatian dari pimpinan ataupun manajemen Organisasi Perangkat Daerah. (OPD). Praktek-praktek tidak sehat yang dilakukan oleh oknum-oknum ASN dalam upaya mendapatkan posisi yang bagus dalam organisasi ataupun untuk memperoleh keuntungan pribadi tidak boleh diberikan ruang untuk berkembang. Dalam skala kecil mungkin politik organisasi tidak terasa mengganggu, tetapi jika dilakukan secara masif dan sudah menjadi penyakit laten birokrasi, lama kelamaan juga akan mengganggu stabilitas kerja maupun kinerja, komitmen organisasional dari karyawan dan pada akhirnya juga akan berpengaruh pada Organizational Citizenship Behavior dari para Aparatur Sipil Negara Bagi peneliti selanjutnya disarankan ketika meneliti topik yang sama mempertimbangkan cakupan responden yang lebih banyak agar hasil yang diperoleh lebih akurat. 


\section{Daftar Pustaka}

Allen, N.J \& J.P. Meyer. (1990). The Measument And Antecedents of Affective, Continuance And Normative Commitment To The Organizations. Journal of Occupations of Pshycology, 63, pp 1-18

Andriani, G. (2012). Organizational Citizenship Behavior dan Kepuasan kerja pada Karyawan. Jurnal Penelitian Psikologi, Vol. 03, No. 01, pp341-354

Chen, Yei-Yi and Fang W. 2008. The Moderating Effect of Impression Management on the Organizational Politics-Performance Relationship. Journal Of Business Ethics 79, pp 263-277.

Daft, R.L. (2003). Manajemen Sumber Daya Manusia. Jakarta: Penerbit Erlangga

Gunawan, H. \& Santosa, T. E. C. (2012). "Politik Organisasi dan Dampaknya Terhadap Komitmen Organisasi, Kepuasan Kerja, Kinerja dan Organizational Citizenship Behavior" Jurnal Manajemen, Volume 2 No.1, pp 13-26, Nopember 2012

Lemy, D. M., Bernarto, I., \& Tulung, J. E. (2013). Pengaruh Bauran Komunikasi Pemasaran Jasa Terhadap Proses Pengambilan Keputusan Mahasiswa Memilih Perguruan Tinggi Swasta di Sulawesi Utara. Jurnal Manajemen DEREMA, Vol. 8 No. 2

Luthans. F. (2006). Perilaku Organisasi, Edisi Kesepuluh, Yogyakarta, PT. Andi

Munandar, A. S . (2004). Peran Budaya Organisasi dalam Peningkatan Unjuk Kerja Perusahaan.Jakarta: Bagian Psikologi Industri dan Organisasi Fakultas Psikologi UI

Pradana, A. F. R., \& Triwijayati, D. (2016). Pengaruh Politik Organisasi Dan Komitmen Organisasi Terhadap Organizational Citizenship Behaviour Karyawan Koperasi Karyawan (Kopkar) Sampoerna Surabaya, Jurnal Ilmu Manajemen Volume 4 Nomor 2

Robbin, S.P. (2003). Prinsip- Prinsip Perilaku Organisasi. Edisi kelima. Jakarta: Erlangga.

Sugiyono. (2006). Statistika Untuk Penelitian. Bandung: Alfabeta.

Sunyoto (2013). “Aplikasi SPSS untuk Smart Riset”, Bandung, Alfabeta.

Wahyuningsih, W., Lukiana, N., \& Irwanto, J. (2014).Pengaruh Kepuasan Kerja dan Komitmen Organisasi Terhadap Organizational Citizenship Behavior (Studi Kasus Pada Karyawan Koperasi Serambi Dana Lumajang). Publika 2(3):1-10. 